\title{
EDITORIAL
}

\section{Mundos conectados: África, Ásia e o Mediterrâneo greco-romano}

"Quand deux peuples se rencontrent, ils se combattent souvent, ils se métissent toujours"

Paul Rivet

A história antiga de povos africanos e asiáticos pouco interessou aos ocidentais. A existência desses povos na antiguidade frequentemente foi percebida a partir de suas relações com gregos e romanos. Essa percepção, longe de estabelecer um entendimento de interações e trocas culturais, com frequência naturalizou discursos hierárquicos sobre relações de dominação de gregos e romanos sobre os outros povos. Nesse projeto de publicação, temos por objetivo não só dar lugar à originalidade dos estudos de povos afroasiáticos na antiguidade, mas, também, às relações estabelecidas por estes com gregos e romanos, para além das ideias normativas de predominância grega e/ou romana presentes nos conceitos de helenização e romanização, por exemplo. Esta perspectiva parte da compreensão da existência de inúmeras sociedades complexas e heterogêneas que se intercruzam em situações e ambientes de fronteiras, por vezes decisivos para os avanços tecnológicos e sociais dos povos envolvidos; povos que se aproximam e se distanciam, com contribuições distintas e complementares.

As experiências do imperialismo e do colonialismo modernos não só instituíram campos disciplinares (ocidentais) voltados aos estudos de povos afroasiáticos (africanismo e orientalismo) como, também, estabeleceram entendimentos só compreensíveis se ligarmos esses campos aos contextos nos quais se desenvolveram. Essa constatação, contudo, não deve reduzir nem o entendimento do africanismo e nem aquele do orientalismo - campos de estudo, hoje, muito mais amplos e mais complexos - às grandes querelas ideológicas nas quais se fundaram.

A obra seminal de Martin Bernal - Black Athena - The Afroasiatic Roots of Classical Civilization, que nos inspirou a criação desta revista e de nosso grupo de estudos e pesquisas, já foi e ainda é objeto de muitas críticas (Lefkowitz, 1996; Moore, 2001; Binsbergen, 2011) que, pertinentes ou não, não lhe tiram o grande mérito de trazer, para o centro do debate acadêmico, as discussões acerca das circulações e trocas culturais entre Grécia e Roma e povos do Oriente Médio, da África e da Ásia ampliando significativamente o campo das pesquisas científicas, por um lado, e 
colaborando, por outro, com a grande atualidade das discussões identitárias contemporâneas, que não cessam de colocar a antiguidade clássica na base.

Oceanos, mares, rios, golfos e desertos foram espaços de conexão entre povos que, $a b$ origine, mantiveram-se em contato, muito antes da expansão do mundo helênico ou da Roma republicana, num vasto cruzamento entre línguas, culturas e religiões. Seja pelo recorrente rompimento de fronteiras levado a cabo pela experiência humana ou pela promoção de trocas comerciais, o mundo dividido entre Oriente e Ocidente nunca conheceu limites absolutos. As literaturas de língua grega ou latina e as evidências materiais expressam o grau dessas interações, que tiveram no Mediterrâneo seu grande palco de entrecruzamentos - espaço de diálogos de culturas, lugar privilegiado das mestiçagens desde longa data. Léopold Sédar Senghor, poeta e escritor senegalês, intelectual engajado na luta pelo reconhecimento das culturas não europeias, para dizer do lugar ocupado pelo Mediterrâneo na história da humanidade relembrava os ensinamentos de Paul Rivet, assim resumindo-os:

"Como o dizia Paul Rivet, meu antigo professor de Antropologia no Instituto de Etnologia de Paris, todas as primeiras civilizações históricas nasceram nas altitudes do Mediterrâneo, nas linhas de encontro dos negros, brancos e amarelos. E, acrescentava ele, às civilizações mediterrâneas - da egípcia à árabe, passando pela grega -, as civilizações iraniana e indiana, chinesa e maia ${ }^{1 "}$.

Em toda essa saga humana, a mestiçagem cultural e biológica é definidora das experiências dos povos na antiguidade, fruto de inalienáveis zonas de contato.

Projeto editorial ambicioso, essa publicação almeja difundir a produção brasileira sobre a Antiguidade (não só no escopo temático da revista) e, ao mesmo tempo, promover a circulação, dentre o público brasileiro, de estudos estrangeiros nesse campo.

Glaydson José da Silva e Gilberto da Silva Francisco

\section{Referências bibliográficas}

BINSBERGEN, Wim van (Ed.). Black Athena comes of age: Towards a constructive reassessment. Berlin, Lit Verlag, 2011.

LEFKOWITZ, Mary R. \& MACLEAN Rogers, Guy (Eds.). Black Athena Revisited. Chapel Hill-London: University of North Carolina, 1996.

${ }^{1}$ Les noirs dans l'Antiquité méditerranéenne. Conferência pronunciada por Léopold Sédar Senghor em 11 de maio de 1977 por ocasião de sua visita oficial ao Principado de Mônaco. Disponível em http://ethiopiques.refer.sn/spip.php?article560 Acessado em: 17/02/2016. 
MOORE, David Chioni (Ed.). Black Athena Writes Back. Martin Bernal responds to his critics. Durham \& London: Duke University Press, 2001. 
